RESEARCH PAPER

\title{
Exploring the impact of foreign direct investment on tobacco consumption in the former Soviet Union
}

\author{
A B Gilmore, M McKee
}

Tobacco Control 2005;14:13-21. doi: 10.1136/tc.2003.005082

See end of article for authors' affiliations

....................

Correspondence to: Dr Anna B Gilmore, European Centre on Health of Societies in Transition, London School of Hygiene and Tropical Medicine, Keppel Street, London WCIE 7HT, UK; anna. gilmore@lshtm.ac.uk

Received 11 July 2003 Accepted

4 December 2004

\begin{abstract}
Background: Tobacco is the single largest cause of morbidity and mortality in the developed world; in the former socialist bloc tobacco kills twice as many men as in the west. Although evidence shows that liberalisation of the cigarette trade through the elimination of import barriers leads to significant increases in consumption, far less is known about the impact of foreign direct investment on cigarette consumption. This paper seeks to explore the impact that the substantial transnational tobacco company investments have had on patterns of tobacco trade and consumption in the former Soviet Union.

Design: Routine data were used to explore trends in cigarette trade and consumption in the 15 countries of the former Soviet Union from the 1960s to the present day. Comparisons were made between trends in countries that have received substantial investment from the tobacco transnationals and countries that have not.

Results: Between 1991 and 2000 cigarette production increased by $96 \%$ in countries receiving industry investment and by $11 \%$ in countries that did not. Over the same period cigarefte consumption increased by 40\%; the increase was concentrated in countries receiving investments. Despite these investments, cigarette imports still outweigh exports and no trade surplus has yet to result.

Conclusions: The findings suggest that liberalisation of inward investment has a significant and positive impact on cigarette consumption and that without appropriate safeguards, market liberalisation may have long term negative impacts on health. Specific trade rules are needed to govern trade and investment in this uniquely harmful product. Implementation of effective tobacco control policies should precede tobacco industry privatisation. International financial organisations pressing for privatisation should ensure this occurs.
\end{abstract}

$\mathrm{T}$ he unprecedented political, economic, and social changes that followed the collapse of the former Soviet Union (FSU) in 1991 and the creation of 15 independent states have had a huge short term impact on health. ${ }^{1}$ The immediate decline in life expectancy has been largely attributed to the rapid increase in cardiovascular deaths and injuries predominantly affecting young and middle aged men..$^{2-4}$ There has, however, been much less attention paid to the longer term impact of these changes.

Market reforms, in particular the rapid and large scale privatisation recommended by the global financial institutions, have had mixed but, to date, largely negative consequences in the FSU. ${ }^{5}$ Market liberalisation has improved access to a variety of products. Some-for example fruit, vegetables, and vegetable oils-should improve health, ${ }^{7}$ but others, including fast food and tobacco, will be detrimental. The transnational tobacco companies (TTCs) entry to and substantial investments ${ }^{8}$ in a region with already high rates of tobacco related disease, and male tobacco related mortality rate twice that seen in the west, ${ }^{9}$ is therefore of particular concern.

Previous studies show that the TTCs forced entry to the Asian markets in Taiwan, Korea, Thailand, and Japan under the threat of US trade sanctions ${ }^{10}$ led to an increase in per capita consumption of about $10 \%{ }^{11}$ Other econometric studies show that greater trade openness (measured using total trade as a share of gross domestic product and import penetration) has a significant and positive impact on tobacco consumption that is greatest in low income countries. ${ }^{12}{ }^{13}$ Such findings are consistent with economic theory which suggests that reducing trade barriers increases tobacco consumption through an increase in both supply and demand, the latter driven by and through competition, which reduces prices and increases advertising expenditure. ${ }^{13}$ The TTCs entry to new markets and the surge in global trade of tobacco products since the 1980s has been enabled by trade liberalisation, driven by bilateral, regional, and multilateral agreements that have reduced both tariff and non-tariff barriers. ${ }^{12}$ Pursuant to the 1994 General Agreement on Tariffs and Trade (GATT), for example, a $42 \%$ rise in global cigarette exports was seen between 1993 and 1996. ${ }^{12}$

However, in addition to exporting to a foreign market, companies can access new markets by establishing or acquiring the facilities to produce in-country and sell directly to the domestic market. Over the last decade such foreign direct investment (FDI) has grown considerably faster than trade, leading some to argue that "globalisation of production" now outweighs "globalisation through trade" in economic importance. ${ }^{14}$ It offers TTCs the advantage of accessing cheaper labour, avoiding developed world regulations on disposal of cigarette production waste, ${ }^{15}$ and lower transport costs. Yet to our knowledge only one attempt has been made to explore the impact of FDI on tobacco consumption. ${ }^{13}$ It suggested that an increase in exchange rate distortions (used to indicate a disincentive to investment) led to a decline in cigarette consumption, leading to the tentative conclusion that FDI should lead to higher levels of cigarette consumption. Certainly the theoretical impact of FDI, in terms of its consequences for supply and demand, is likely to be similar to that of trade liberalisation. In addition FDI gives

Abbreviations: FAO, United Nations Food and Agriculture Organization; FDI, foreign direct investment; FSU, former Soviet Union; GATT, General Agreement on Tariffs and Trade; IMF, International Monetary Fund; TTCs, transnational tobacco companies; USDA FAS, US Department of Agriculture, Foreign Agricultural Service 
the transnationals additional economic and political leverage within the country concerned. ${ }^{16}$

Between 1992 and 2000 the TTCs invested over $\$ 2.7$ billion in the tobacco industries of 10 of the 15 FSU states, accounting for between $1 \%$ and over $31 \%$ of the total FDI in these countries. ${ }^{8}$ This led to major changes including the introduction of branding and advertising which were previously unknown. ${ }^{8}{ }^{17}$ Unlike the industry's entry to Asia, there was little opposition to the TTC's entry. The newly created countries were in the process of developing their own constitutions with new legislative and taxation systems, so none had in place, nor was able to rapidly enact, tobacco control laws. Nor did they have established tobacco control or civil society groups to oppose industry pressure. ${ }^{8}{ }^{17}$ As elsewhere, the TTCs used smuggling as a major market entry technique $^{17}$ and in countries where they have not yet invested, smuggling rates remain high. ${ }^{8} 18$

Despite the scale of these changes, little is known about their impacts. This paper therefore seeks to explore the impact that foreign direct investment has had on patterns of cigarette trade and, in turn, on cigarette consumption in the FSU. In so doing it aims to add to the growing body of evidence on the impact that trade liberalisation and transition from a socialist to a market economy has on health. Given evidence that the International Monetary Fund (IMF) is pressuring countries to privatise their tobacco industries and making privatisation a prerequisite for loans, ${ }^{19}{ }^{20}$ it is becoming increasingly important to understand what impact privatisation might have. The economic turmoil accompanying transition, periods of rapid inflation, and the introduction of new currencies and redenomination of old ones, makes interpretation of financial data, including cigarette prices, across these 15 countries extremely difficult, so this paper takes a descriptive rather than an econometric approach.

\section{METHODS}

Three main data sources were used, the United Nations Food and Agriculture Organization (FAO) database which provides data from 1961 onwards, ${ }^{21}$ the United Nations Commodity Statistics Yearbooks which provide cigarette production data from 1963, and the US Department of Agriculture, Foreign Agricultural Service (USDA FAS) data which are available from 1960. ${ }^{22}$ The accuracy and completeness of the data were compared with each other and with other sources in order to identify the most appropriate source for each measure of interest (table 1).

All data are presented for the region as a whole, the USSR until transition, and the FSU as a whole post-transition. The demise of the FSU does not present problems when examining production or consumption data over time, with data simply aggregated where necessary. It does, however, lead to potential difficulty when comparing import and export data as products traded between different parts of the USSR did not, until the collapse of the USSR, contribute to international trade figures. The FAO database allows for this transfer by providing trade figures for the old boundaries (that is, for the USSR) up until 1995 and for the new boundaries from 1992 to 1999, giving a four year period of overlap. By contrast USDA simply provides data for the old boundaries up to 1991 and for the new boundaries from 1992 (Arnella Trent, USDA, personal communication). For trade figures we therefore present both sets of data up to 1995 to examine the impact that these configuration changes had.

Where not already provided, cigarette consumption was calculated from USDA data using the formula: production + imports - exports. Consumption per capita was calculated for the population as a whole using mid year population estimates from the United Nations Demographic Yearbooks for the years to $1990^{23-25}$ and the World Health Organization
Table 1 Data sources and details

\begin{tabular}{|c|c|c|}
\hline Data & Data source & $\begin{array}{l}\text { Year (boundary for } \\
\text { import or export data) }\end{array}$ \\
\hline $\begin{array}{l}\text { Tobacco leaf } \\
\text { production }\end{array}$ & $\begin{array}{l}\text { UN FAO database } \\
\text { (agricultural production } \\
\text { section) }\end{array}$ & $1961-2000$ \\
\hline $\begin{array}{l}\text { Cigarette } \\
\text { production }\end{array}$ & USDA & 1960-2001 \\
\hline $\begin{array}{l}\text { Tobacco leaf } \\
\text { imports and } \\
\text { exports }\end{array}$ & $\begin{array}{l}\text { UN FAO database } \\
\text { (agriculture and food trade } \\
\text { section). }{ }^{.6}\end{array}$ & $\begin{array}{l}\text { 1961-1995 using USSR } \\
\text { boundaries 1992-1999 } \\
\text { using NIS boundaries }\end{array}$ \\
\hline \multirow[t]{2}{*}{$\begin{array}{l}\text { Cigarette } \\
\text { imports and } \\
\text { exports }\end{array}$} & $\begin{array}{l}\text { UN FAO database } \\
\text { (agriculture and food trade } \\
\text { section) }\end{array}$ & $\begin{array}{l}1961-1995 \text { using USSR } \\
\text { boundaries }\end{array}$ \\
\hline & USDA & $\begin{array}{l}1960-1989 \text { using USSR } \\
\text { boundaries 1990-2001 } \\
\text { using NIS boundaries }\end{array}$ \\
\hline $\begin{array}{l}\text { Cigarette } \\
\text { consumption }\end{array}$ & USDA & $1960-2001$ \\
\hline $\begin{array}{l}\text { Mid year } \\
\text { population }\end{array}$ & $\begin{array}{l}\text { United Nations Demographic } \\
\text { Yearbooks }\end{array}$ & 1960-1989 \\
\hline estimates & $\begin{array}{l}\text { WHO Health for All } \\
\text { database }^{26}\end{array}$ & 1990-2001 \\
\hline $\begin{array}{l}\text { Mid year } \\
\text { population } \\
15+\text { estimates: }\end{array}$ & $\begin{array}{l}\text { WHO Health for All } \\
\text { database }^{26}\end{array}$ & 1990-2001 \\
\hline
\end{tabular}

USDA, US Department of Agriculture; UN FAO, United Nations Food and Agriculture Organization; WHO, World Health Organization.

Health for All database (which uses data from the United Nations Population Division) for the years 1990 onwards. ${ }^{26}$ Whole population data were used rather than the population aged 15 and over as accurate data on the latter were not available across the whole time period. For the period 1991 onwards we examined consumption per capita using the population aged 15 years plus.

The newly independent states can be split into two groups, those without direct industry investments (Belarus, Georgia, Moldova, Tajikistan, and Turkmenistan) and those with substantial investment from the tobacco transnationals in the early to mid 1990s (Latvia, Lithuania, Estonia, Russia, Ukraine, Kazakhstan, and Uzbekistan). ${ }^{8}$ Trends in tobacco leaf imports, and cigarette production and consumption, were compared in these two groups of countries. Kyrgyzstan, Armenia, and Azerbaijan were excluded from these analyses because although they have now received investments from the tobacco industry this only occurred after 1997, considerably later than the other countries, and it was felt that insufficient time had elapsed for these investments to have had an observable impact.

\section{RESULTS}

\section{Tobacco leaf production}

Agricultural production of tobacco has varied greatly over time, with a drop in the late 1970s and early 1980s, a peak in the mid 1980s, followed by a notable decline until the mid 1990s (fig 1). This recent decline is consistent with reported shortfalls in tobacco during this period. It appears to reflect a number of factors ${ }^{27}$ including policies to discourage production as part of Gorbachev's health campaign in the 1980s, droughts and wars, and the demise of Soviet subsidies for agricultural production. ${ }^{28}$ Gorbachev's health campaign focused largely (and effectively) on reducing alcohol consumption, ${ }^{29}$ but some believe it also aimed to reduce cigarette consumption through reducing supply of leaf and manufactured cigarettes. Others, however, have suggested that the campaign really only served to hide the underlying economic difficulties that were driving down production.

In the mid 1990s production stabilised and now appears to be increasing. The traditional tobacco producing areas of 


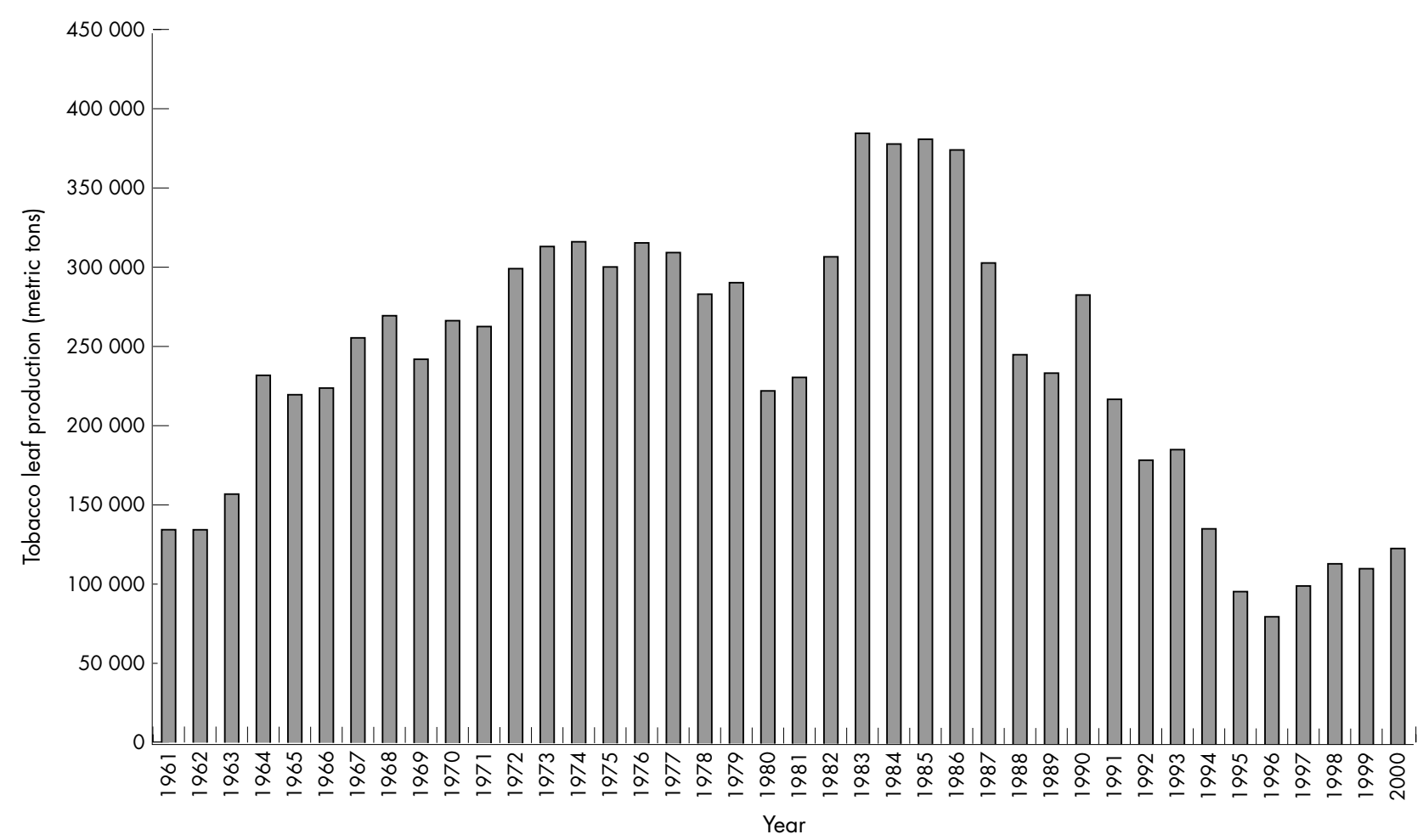

Figure 1 Tobacco leaf production in the USSR/former Soviet Union (FSU), 1961-2000. Source: UN FAO database agricultural production.

Moldova, Azerbaijan, and Kyrgyzstan ${ }^{30}$ are all recovering from slumps in production post-transition, although little increase in production has yet been seen in Azerbaijan. ${ }^{31}$ Interestingly, production has also increased in countries that have not traditionally been major tobacco producers, notably Uzbekistan and Kazakhstan, reflecting foreign investment by British American Tobacco (BAT) and Philip Morris respectively in their leaf growing industries ${ }^{32-34}$ (fig 2).

\section{Cigarette production}

Cigarette production fluctuated from 1960 with a slow, overall upward trend that peaked in 1986 (fig 3). The rapid

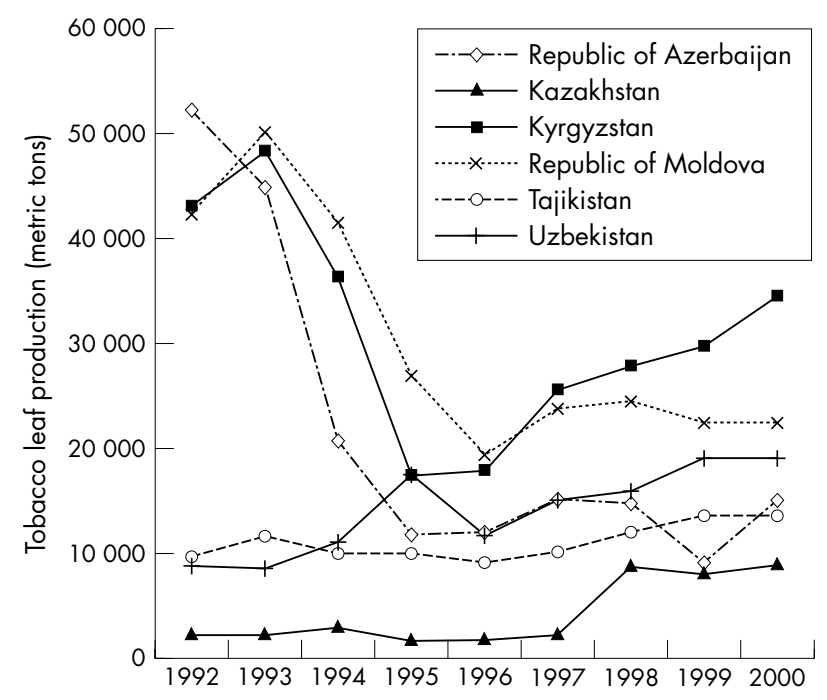

Figure 2 Tobacco leaf production in selected countries, 1992-2000. Source: UN FAO database agricultural production. decline then seen has been attributed variously to obsolete manufacturing equipment, shortages of raw materials (tobacco leaf, paper, and filters) and, once again, Gorbachev's health campaign. Since the mid 1990s cigarette production has increased almost exponentially and has now reached higher levels than ever previously seen, with a $76 \%$ increase between 1991 and 2000. Production in countries receiving foreign investment increased by $96 \%$ during this period, compared with only $11 \%$ in countries not receiving investment (fig 3).

\section{Imports and exports}

Imports of cigarettes fluctuated, albeit with an overall upward trend between 1960 and 1984 (fig 4). A rapid decline then occurred through the rest of the 1980s. In 1990 and 1991 imports suddenly rose due to the airlift into the USSR of a reported 34 billion manufactured cigarettes by Philip Morris and RJ Reynolds. ${ }^{35}$ USDA data suggest that imports then increased steadily between 1993 and 1995, declining rapidly thereafter. Importantly, this temporary increase was seen only in those countries where the transnationals had invested. These patterns are consistent with the production data described above, suggesting that imports increased until local production picked up from 1995 onwards.

Before transition tobacco leaf imports fluctuated over time (fig 5). It appears that shortfalls in local leaf production (fig 1) were covered by increasing imports. Since 1990, leaf imports have increased steadily, with the increase seen almost exclusively in countries with transnational tobacco investments.

Tobacco leaf and cigarette exports from the USSR varied between 1961 and 1990 with no clear trend but were always small, at under 5000 metric tonnes and 5 billion units (one unit $=1$ cigarette), respectively. A sudden increase in cigarette exports occurred in the mid 1990s (fig 6), a trend that appears to have continued. In contrast leaf exports have not increased overall since transition (data not shown). 


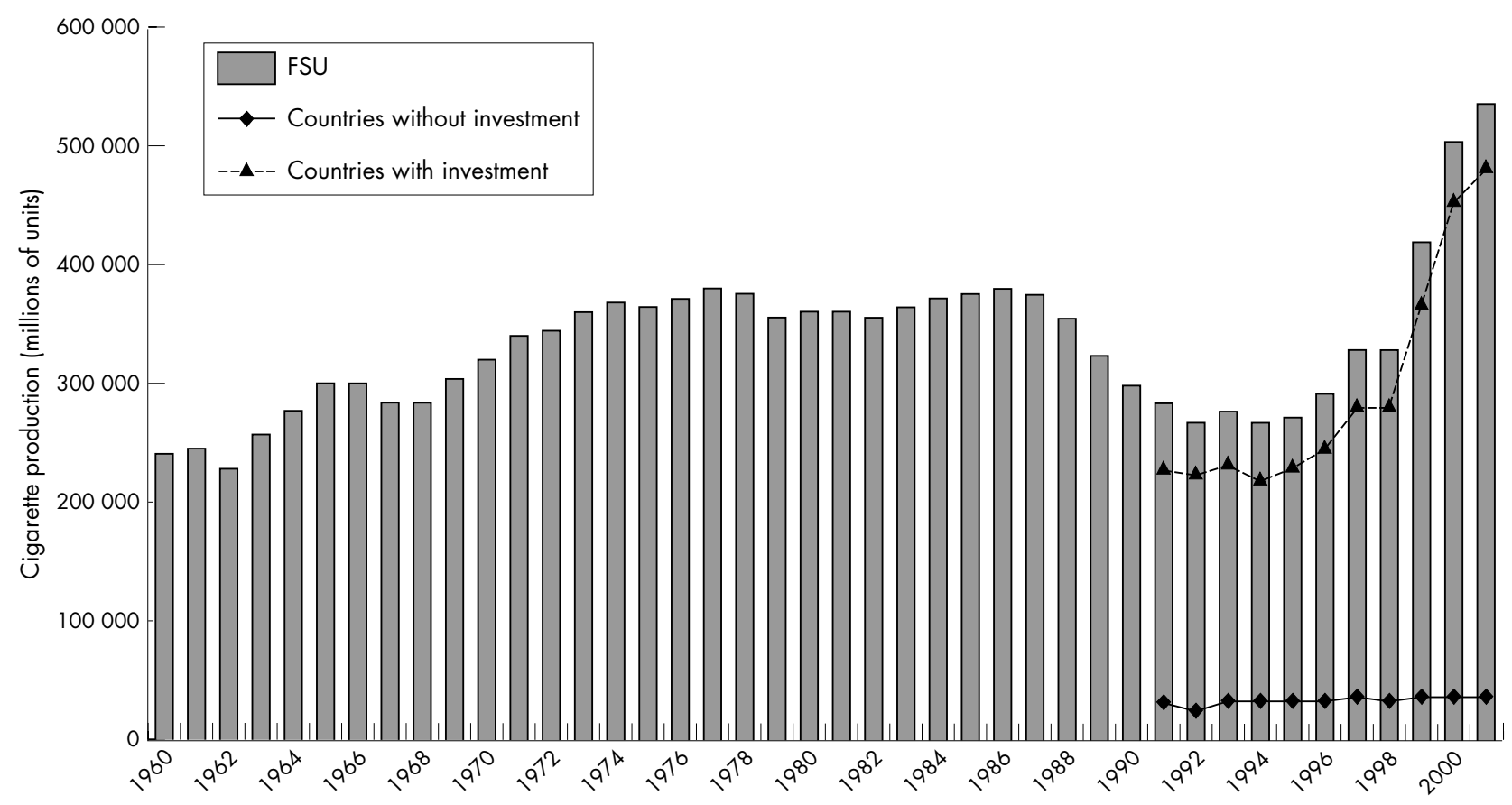

Figure 3 Cigarette production in the USSR/FSU, 1960-2001. Source: USDA data. Note: 2001 data are estimates.

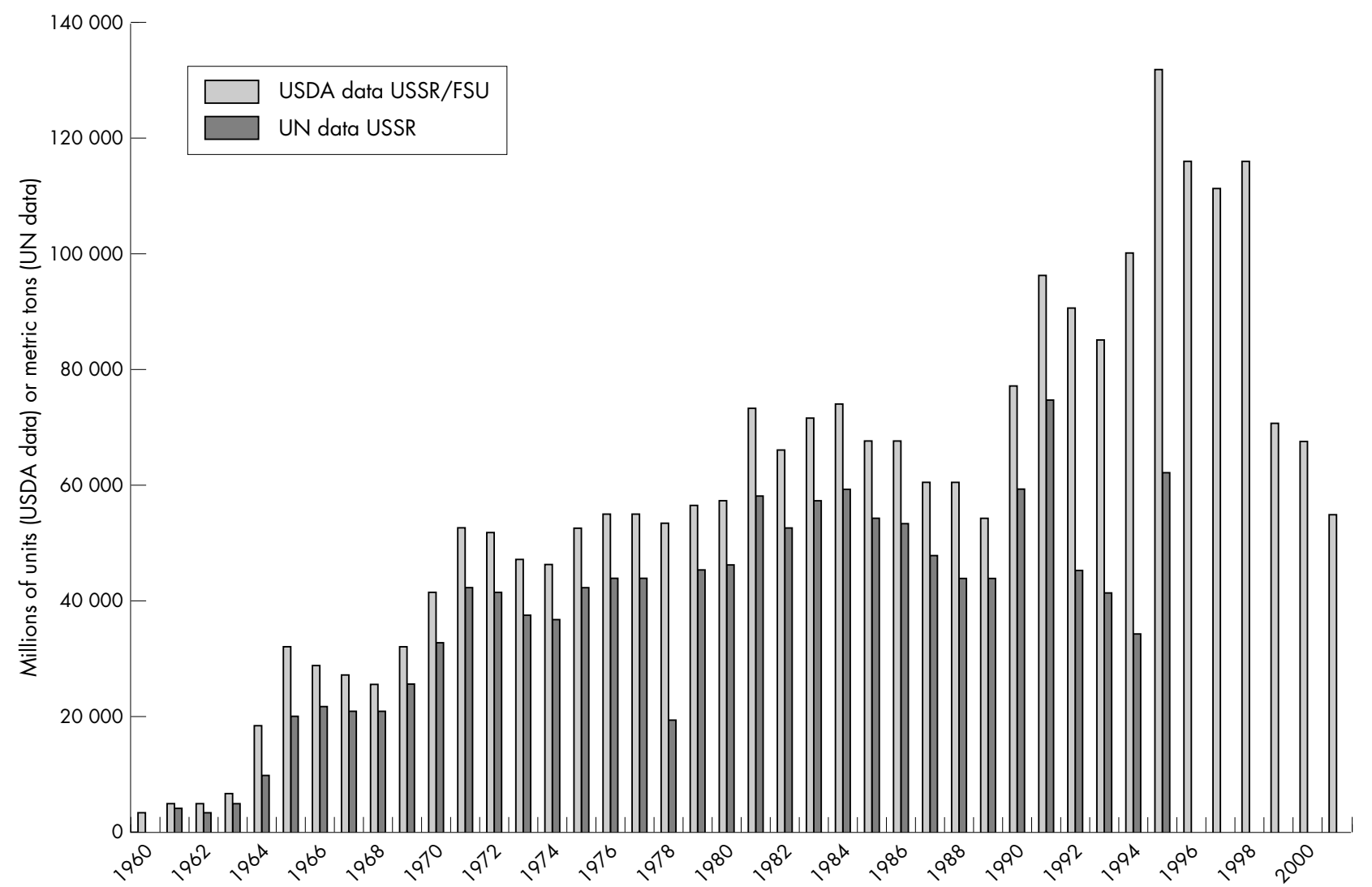

Figure 4 Cigarette imports in the USSR/FSU, 1960 to 2001. UN data are given for the USSR configuration and USDA data for the USSR configuration until 1991 and the FSU from 1992 onwards. Source: USDA and UN FAO agriculture and food trade database. Note: USDA 2001 data are estimates. 


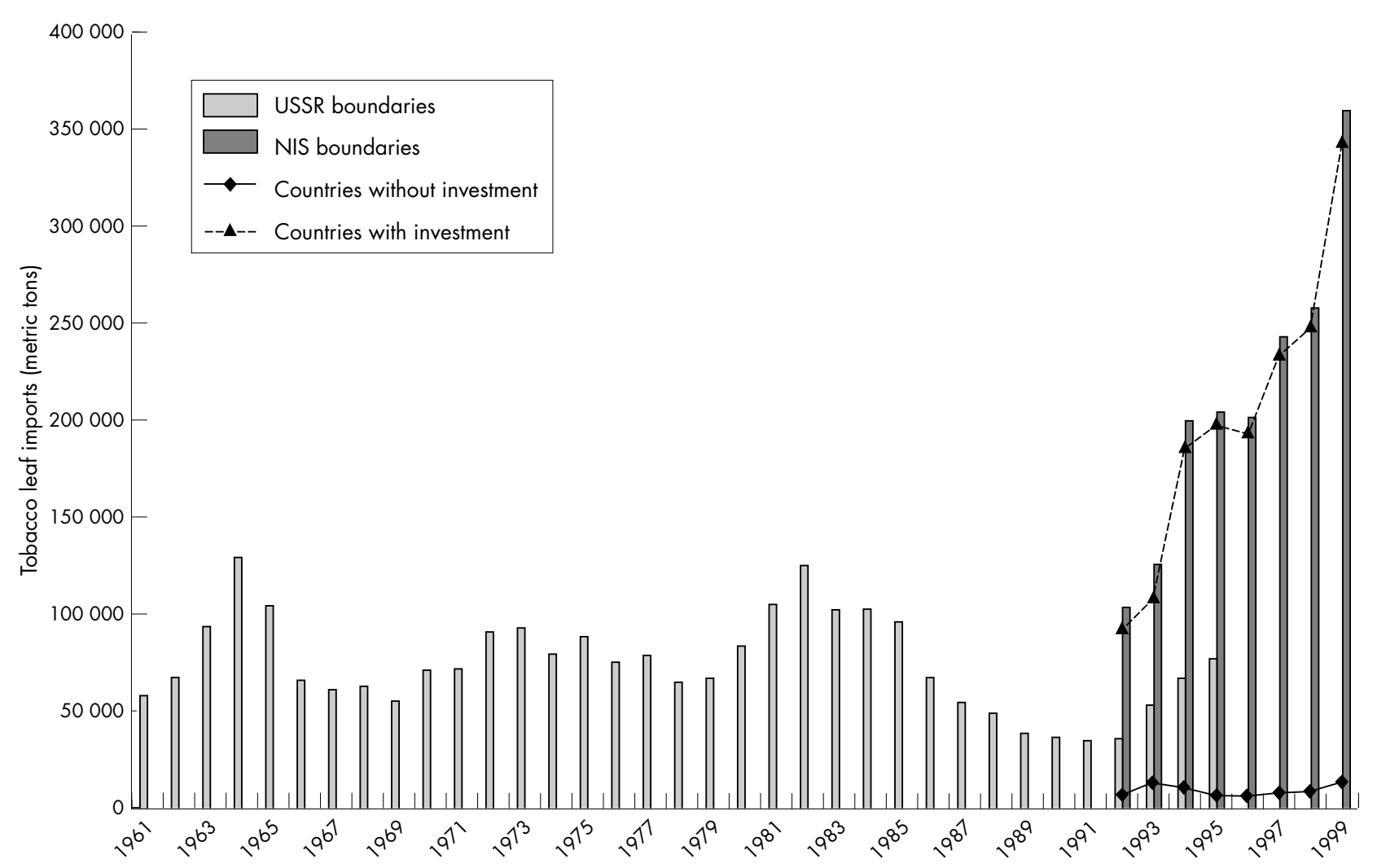

Figure 5 Tobacco leaf imports in the USSR/FSU, 1961-1999. Source: UN FAO agriculture and food trade database.

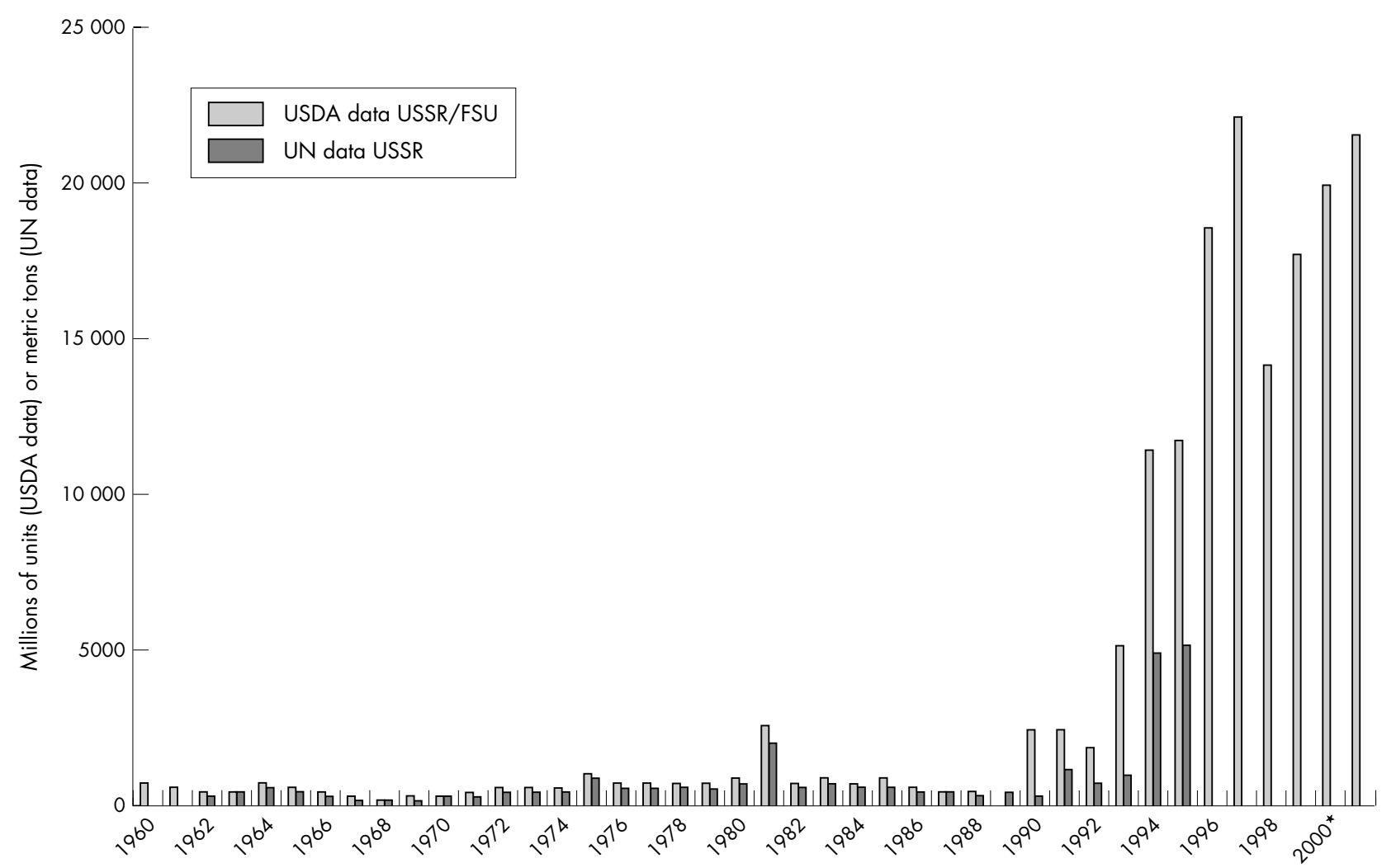

Figure 6 Cigarette exports in the USSR/FSU, 1960-2001. UN data are given for the USSR configuration and USDA data for the USSR configuration until 1991 and the FSU from 1992 onwards. Source: USDA and UN FAO agriculture and food trade database. Note: USDA 2001 data are estimates. 


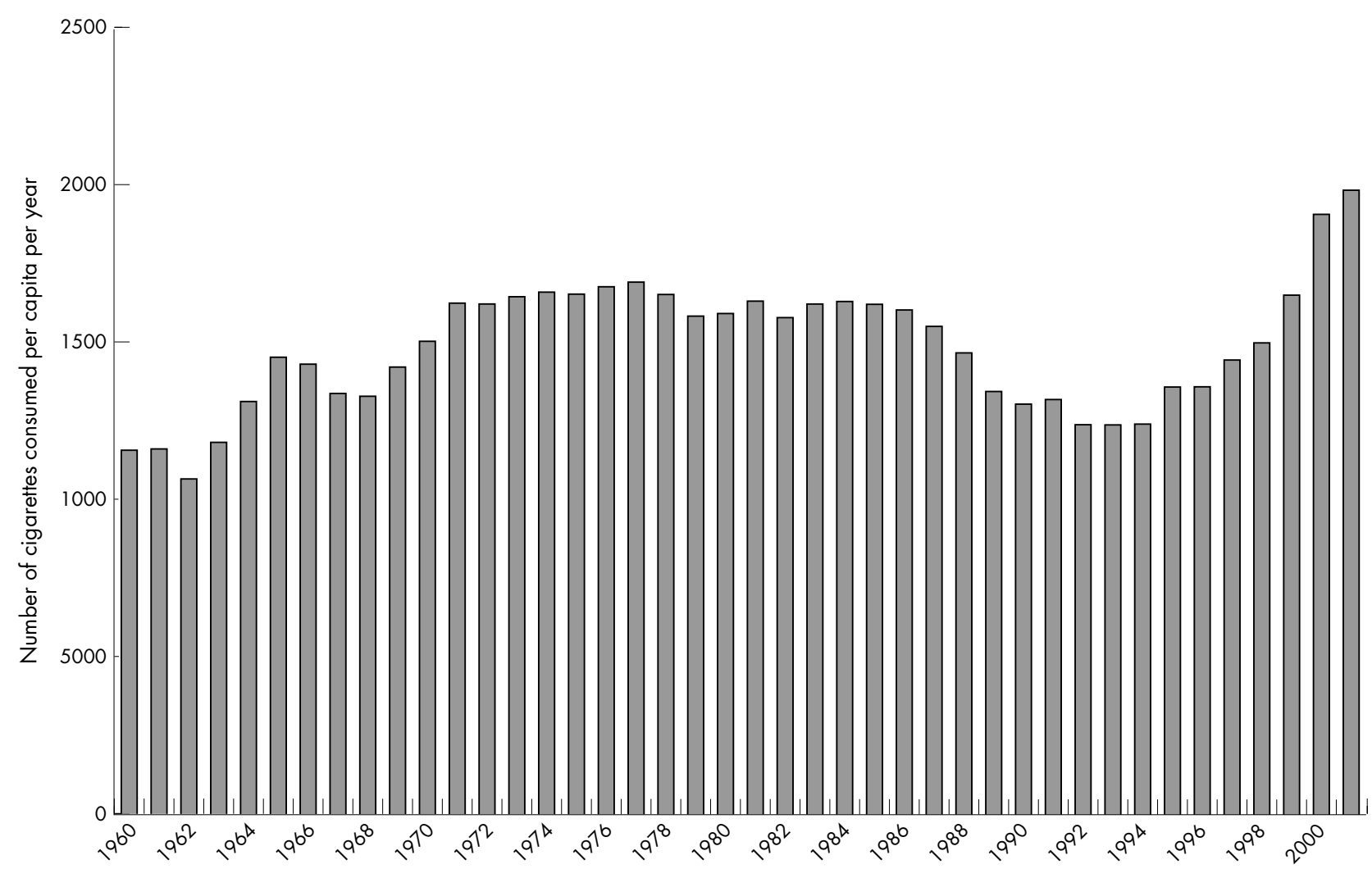

Figure 7 Cigarette consumption per capita in the USSR/FSU (all ages), 1960-2001. Source: Cigarette consumption-USDA data. Population dataUN data to 1989 taken from UN demographic yearbooks, WHO data from 1990 taken from WHO HFA database. Note: 2001 data are estimates.

\section{Cigarette consumption}

Per capita cigarette consumption increased between 1960 and the mid 1970s but then stabilised for a decade until the shortfalls in production and imports led to a rapid decline until the mid-1990s (fig 7). Since then consumption has increased almost exponentially and now totals almost 575 billion cigarettes per year, considerably higher than the previous peak. Over the period 1991 to 2000 per capita consumption among those aged 15+ increased by $40 \%$ in all countries combined, $51 \%$ in countries that had received tobacco industry investments compared with a $3 \%$ fall in countries that had not, with similar figures seen for the period 1991 to 2001 (table 2).

\section{DISCUSSION}

These data suggest that the transition to a market economy with its accompanying liberalisation of trade and investment, which permitted entry of the tobacco transnationals, has had a major impact on tobacco trade and consumption in the FSU. Cigarette consumption has increased almost exponentially in line with the rapid increase in cigarette production. Moreover, these large increases in consumption have been concentrated in countries receiving tobacco industry investment. Tobacco leaf production declined, largely due to the disruption of transition, but has now started to increase, not only in traditional producing areas but also in Uzbekistan and Kazakhstan, following British American Tobacco and Philip Morris investments. Cigarette imports increased only temporarily and in countries receiving industry investments, seemingly until output from the updated local production facilities had reached a sufficient level, while exports have seen a continued but smaller rise insufficient to result in a trade surplus.

Before considering the results in any detail, it is necessary to consider data accuracy. There are three main concerns in this area: data collection systems, smuggling, and illegal

Table 2 Cigarette consumption per capita 15+ in the former Soviet Union (FSU) as a whole, and in countries with and without tobacco transnational investments

\begin{tabular}{|c|c|c|c|c|c|c|c|c|c|c|c|c|c|}
\hline & 1991 & 1992 & 1993 & 1994 & 1995 & 1996 & 1997 & 1998 & 1999 & 2000 & $2001^{*}$ & $\begin{array}{l}\text { Percentage } \\
\text { increase } \\
1991-2000\end{array}$ & $\begin{array}{l}\text { Percentage } \\
\text { increase } \\
\text { 1991-2001 }\end{array}$ \\
\hline $\begin{array}{l}\text { Countries without } \\
\text { investment } \\
\text { Countries with }\end{array}$ & 2024 & 1757 & 1832 & 1907 & 1890 & 1940 & 1954 & 1959 & 1981 & 1960 & 1996 & $-3 \%$ & $-1 \%$ \\
\hline investment & 1712 & 1653 & 1641 & 1623 & 1805 & 1784 & 1908 & 1972 & 2184 & 2580 & 2679 & $51 \%$ & $56 \%$ \\
\hline FSU as a whole & 1766 & 1661 & 1651 & 1647 & 1798 & 1783 & 1888 & 1944 & 2127 & 2468 & 2529 & $40 \%$ & $43 \%$ \\
\hline
\end{tabular}

Countries without investment include: Belarus, Georgia, Moldova, Tajikistan, Turkmenistan.

Countries with investment include: Estonia, Kazakhstan, Latvia, Lithuania, Russia, Ukraine, Uzbekistan.

Armenia, Azerbaijan, and Kyrgyzstan appear only in the "FSU as a whole" group and this accounts for differences between this and the other two groups.

*2001 consumption and population data are estimates. For Turkmenistan, 1999 and 2000 population data are also estimates based on 1998 data. 
production. With independence, each country had to establish new data collection systems and this caused difficulties, particularly in the early 1990s. Thus, while the Statistical Committee of the Commonwealth of Independent States publish trade statistics, they do not cover all years or all countries, and the definitions of tobacco related categories are inconsistent. ${ }^{36}$ Similarly, the United Nations Statistical Division Comtrade database ${ }^{37}$ does not contain data for some countries in the region such as Uzbekistan.

Problems with data appear to have mainly affected the smaller central Asian states which contribute less to the regional total. In addition, the gaps are predominantly in export data for the early 1990s which, given the small scale of exports relative to production or imports, will have relatively little impact on final consumption figures. However, in some other countries, at particular times, there are some contradictions between data sources that cannot be reconciled. The USDA has attempted to overcome these problems by using a variety of sources to generate best estimates in the absence of credible data and, while it cannot be considered perfect, we believe it is the most comprehensive and consistent source of data available at present.

Import and export data include only officially traded cigarettes and are therefore problematic given that smuggling was and is a major issue in the region. ${ }^{17}{ }^{18}$ As much of the smuggling, particularly in more recent years, is likely to occur between countries within the region, this problem is overcome to some extent by considering the FSU as a whole. Based on the fact that cigarette exports far outweigh imports, it is estimated that approximately one third of global cigarette exports are smuggled..$^{38}$ Our data show the opposite occurring in this region. Nevertheless, the most likely impact of smuggling on the data presented in this paper is to underestimate imports to and hence consumption in countries without substantial TTC investments, while also perhaps underestimating exports from countries that have received investments. This will exaggerate the different scale of increases in consumption between countries with and without tobacco industry investments and may account for part of these differences. Overall, the three issues are likely to underestimate consumption in the immediate post-transition period when data problems, illegal production, and smuggling (used as an industry market entry strategy) were greatest. ${ }^{39}$

While not wishing to overlook these serious concerns, the data presented here are the most comprehensive available and, despite their weaknesses, allow a preliminary assessment of an important issue. Although data sources often overlap, wherever possible, data from at least two sources were obtained and compared. FAO data were used for tobacco leaf production as they were more consistent with industry data on production levels in the post-transition period, ${ }^{28}{ }^{40}$ and because the trade data have the advantage of being presented in metric tons across the whole time period. UN and USDA data on imports, exports, and production differed somewhat more in the post-transition period, particularly in the early 1990s, although overall trends were similar. USDA data were more complete and believed to be more accurate for consumption (and for the underlying import, export, and production data). They were, for example, more consistent with the publication World Tobacco Trends $^{41}$ and with ERC data ${ }^{42}$ and had the additional advantage of being more up to date. Other sources, including the World Tobacco File, ${ }^{43}$ did not have data for all countries in the region and could not therefore be used.

Attempts to validate our findings also suggest they are reasonably robust. For most countries, our estimates of cigarette consumption per capita were very similar to those provided by ERC which also found that between 1990 and
2000 consumption increased by $57.3 \%$ in Russia. ${ }^{42}$ In addition, survey data suggests that smoking prevalence has been rising particularly among young women. ${ }^{44-46}$ Production figures were consistent with our previous assessment of production capacity. ${ }^{8}$ We estimated that in 10 countries receiving investments before 2001 , production capacity in factories with transnational investments totalled 416 billion cigarettes. Such factories are thought to account for between $80-90 \%$ of production $^{39}{ }^{47}$ consistent with the data presented here that in 2000, production in these countries totalled 459 billion, the extra 43 billion presumably accounted for by factories without TTC investments.

This current level of consumption (2529 cigarettes per capita in 2001) is high by international standards although similar to levels seen in much of central and eastern Europe. ${ }^{26}$ The increase in consumption has been far greater in countries that have received major tobacco industry investments (56\%) than in countries that have not $(-1 \%)$. While some of the overall increase is caused by the artificially low consumption levels seen around independence, and some of the differential increase in countries receiving investments is due to undocumented smuggling from these countries in the latter half of the decade (or smuggling to these countries in the first half), it is clear that consumption has now increased well above its previous peak in the mid 1980s. The increase in consumption is particularly notable for two reasons. Firstly, the tobacco epidemic in the FSU, at least among men, has been established for some time. Although historical data on smoking habits are scarce, contemporary studies asking about ever smoking, combined with data on lung cancer mortality, ${ }^{48}$ suggest that male smoking must have become widespread during the first half of the 20th century, probably contemporaneously with the establishment of the habit in the USA or UK. In addition, the region's first cigarette factories and brands were established in the 1850s and 1860s. ${ }^{34} 49$ Although Soviet women did not smoke in large numbers until recently, the classic description of the progress of the tobacco epidemic would suggest that consumption should now be steady or declining as appeared to be the case in the 1970 s to 1980s, not increasing to the extent indicated here. Second, after independence, most countries experienced sustained economic recessions, with pronounced increases in poverty, which would be expected to reduce rather than increase consumption.

As noted earlier, trade liberalisation can work in several ways to increase consumption. Although elucidating the precise mechanisms in this instance is impossible because of the absence of detailed data on, for example, price, compounded by the extreme financial volatility during this period, it appears that many factors seen elsewhere were also in operation here, albeit with some minor differences. An increased supply of cigarettes was seen but occurred through increased production rather than imports. Even where companies planned to or successfully established monopolies ${ }^{80}$ and then exerted pressure on governments to close the market to outside competition through both tariff and non-tariff barriers, ${ }^{51}{ }^{52}$ competition was more intense than in the Soviet era. Moreover, industry documents suggest that, in terms of marketing, such markets would be treated as though they were competitive. ${ }^{50}$ Thus advertising increased virtually everywhere, even where the TTCs had manufacturing monopolies. The TTCs were soon identified as the largest advertisers on Russian television and radio and in at least four of the former Soviet states the tobacco transnationals ranked among the top three advertisers..$^{53}{ }^{54}$ With the advent of television advertising bans (in Russia, for example) industry spend shifted to other media-tobacco is now the product most heavily advertised outdoors with three major transnationals ranked as first, second, and third heaviest advertisers. ${ }^{55}$ An almost identical 
pattern is seen in Ukraine and Belarus..$^{55}$ Tobacco industry documents indicate that young people, women, opinion leaders, and urban residents were specifically targeted and the allure of western products was used to attract smokers. ${ }^{17} 50$ 56-58 This targeted advertising combined with the increased production of filter brands, and the introduction of milder brands and brands targeted specifically to women to a market previously dominated by coarse filterless or papirossy cigarettes, must have encouraged new smokers (particularly women) to take up the habit as the TTCs predicted. ${ }^{50}$ Indeed our studies in several countries have found smoking among women to be far higher in cities, where advertising has been concentrated. ${ }^{45} 5960$

But why then was the increase in consumption in the FSU (approximately $40 \%$ ) so much greater than in Asia (10-20\%)? One factor is data artefact, in particular the artificially low consumption level at the end of the 1980s. Another is the absence of effective tobacco control policies, or even organised tobacco control groups that might have counterbalanced industry pressure. However, it is argued here that a major factor was the enormous economic and political leverage of the tobacco industry on account of their major contribution to FDI in the recipient countries. ${ }^{8}$ It is also likely that efforts to stimulate demand succeeded because of the vulnerability of the population in a time of rapid transition and great uncertainty. Our research on factors influencing smoking behaviour in Ukraine highlighted the role of deterioration in social position (a proxy for of the stress of changes associated with transition), as well as unemployment and poverty as important determinants of current smoking. ${ }^{45}$

Over the period 1991 to 2000 , annual cigarette production increased by over 200 billion, a 76\% increase. Yet, despite the increase in production, exports have only increased by a fraction of this amount to a total of just over 20 billion for the region. Meanwhile, imports, which rose initially, have declined to approximately 50-60 billion. Overall, therefore, despite significant investment in the region's tobacco industry, the overall trade balance in cigarettes remains negative. Moreover the rapid increase in tobacco leaf imports by countries receiving tobacco industry investment may further increase their trade deficit. The shift in consumer preferences towards new blended cigarette varieties, coupled with the increase in consumption, has led to a decline in the proportion of tobacco imported from former Soviet republics in favour of imports from, for example, India, Greece, Turkey, Italy, Spain, Zimbabwe, and Brazil..$^{61}{ }^{62}$

Ideally, further work would be useful to verify these findings on a country by country basis using more detailed econometric analysis to control for changes in incomes, price, and advertising over this period. Researchers studying other parts of the world have examined this issue by undertaking such analyses and we considered doing so here, but it rapidly became clear that many factors (not only affecting data on tobacco) that arose as countries struggled to establish data systems, tackle the informal economy, introduce new currencies, deal with hyperinflation, build state structures and, in some cases, define national frontiers following the outbreak of hostilities, made it impossible to obtain sufficient valid and meaningful data in which one could be confident. Nevertheless, we conclude tentatively that similar to trade liberalisation, liberalisation of inward investment leads to an increase in cigarette consumption. Although liberalisation has led to the investment of much needed capital, no other benefits have accrued from tobacco industry investments. Trade deficits initially increased and, although now stabilised, have yet to decline and leaf deficits are likely to increase. Profits from tobacco sales will accrue to investors outside the region, while the considerable costs of long term
What this paper adds

This paper shows that liberalisation of inward investment has had a significant and positive impact on cigarette consumption in the countries of the former Soviet Union. It highlights the need for appropriate safeguards to govern trade and investment in this uniquely harmful product.

health consequences will be borne by host countries with already high premature mortality rates.

The World Bank plays a major role in global tobacco control and since 1991 has not loaned for or invested in the tobacco industry. ${ }^{63}$ Despite the growing body of evidence on the impact of trade liberalisation on tobacco consumption, the World Bank suggests trade restrictions would be potentially counterproductive, and recommends restricting supply side measures to the control of smuggling. ${ }^{63}$ Others, however, argue that international treaties that have liberalised trade should develop specific rules to govern tobacco as they have done other uniquely harmful products such as weapons and hazardous waste-products that kill far fewer people. ${ }^{94}$ In the meanwhile, a basic first step would be to protect markets before their opening through ensuring the presence of comprehensive tobacco control programmes with comprehensive advertising bans and effective taxation policies as absolute prerequisites (although the Thai experience suggests that this may be insufficient). The IMF which may exert pressure for industry privatisation (as it did, for example, in Moldova ${ }^{19}{ }^{20}$ ) and the World Bank have a particular responsibility in this regard. Unlike the World Bank, which recognises the economic consequences of tobacco use and poor health, this may require a major volte-face by the IMF. In addition, the case can be made for requiring health impact assessments of the short and long term health and economic impacts of tobacco industry privatisation where further privatisations are recommended.

\section{Authors' affiliations}

A B Gilmore, M McKee, European Centre on Health of Societies in Transition, London School of Hygiene and Tropical Medicine, London, UK

Funding: This work was supported in part by the National Cancer Institute, US National Institutes of Health, grant number 1 RO1 CA91021-01.

Conflict of interest: AG is board member of ASH-UK (unpaid)

The opinions are those of the authors alone.

\section{REFERENCES}

1 McKee M. The health effects of the collapse of the Soviet Union. In: Leon D, Walt G, eds. Poverty and inequality in health. Oxford: University Press, 2001:17-36.

2 Shkolnikov V, McKee M, Leon DA. Changes in life expectancy in Russia in the 1990s. Lancet 2001;357:917-21.

3 Cockerham WC. The social determinants of the decline of life expectancy in Russia and Eastern Europe: a lifestyle explanation. J Health Soc Behav 1997;38:1 17-30.

4 Walberg P, McKee M, Shkolnikov V, et al. Economic change, crime and mortality crisis in Russia: a regional analysis. BMJ 1998;317:312-8.

5 Stiglitz J. Globalization and its discontents. London: Allen Lane, the Penguin Press, 2002.

6 World Bank. Transition the first ten years: analysis and lessons for Eastern Europe and the Former Soviet Union. Washington DC: The World Bank, 2002.

7 Zatonski WA, McMichael AJ, Powles JW. Ecological study of reasons for sharp decline in mortality from ischaemic heart disease in Poland since 1991. BMJ 1998;316:1047-51.

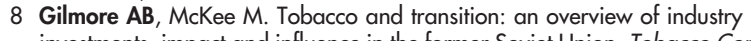
investments, impact and influence in the former Soviet Union. Tobacco Control 2004; 13:136-42. 
9 Peto R, Lopez AD, Boreham J, et al. Mortality from tobacco in developed countries: indirect estimation from national vital statistics. Oxford: Oxford University Press, 1994

10 Council on Scientific Affairs. The worldwide smoking epidemic: tobacco trade, use and control. JAMA 1990;263:3312-18.

11 Chaloupka FJ, Laixuthai A. US trade policy and cigarette smoking in Asia. National Bureau of Economic Research Working Paper No. 5543, 1996.

12 Taylor A, Chaloupka FJ, Guindon E, et al. The impact of trade liberalisation on tobacco consumption. In: Jha P, Chaloupka F, eds. Tobacco control in developing countries. Oxford: Oxford University Press, 2000.

13 Bettcher D, Subramaniam C, Guindon E, WTO Secretariat, Taylor A, et al. Confronting the tobacco epidemic in an era of trade liberalisation. Geneva: WHO, TFI, 2001.

14 McCorriston S. Recent developments on the Links between Foreign Direct Investment and Trade. July 2000. Revised version of a paper presented at the IATRC session on 'Explaining Patters of International Trade', New Orleans, December 1999. http://www.ex.ac.uk/sobeResearch/ DiscusssionPapersEcon/Econ2000/Econ0005.html (Accessed 16 January 2002).

15 Novotny T, Zhao F. Consumption and production waste: another externality of tobacco use. Tobacco Control 1999;8:75-80.

16 Callard C, Collishaw N, Swenarchuk M. An introduction to international trade agreements and their impact on public health measures to reduce tobacco use Physicians for a Smokefree Canada, 2001.

17 Gilmore AB, McKee M. Moving East: how the transnational tobacco industry gained entry to the emerging markets of the former Soviet Union-part II: an overview of priorities and tactics used to establish a manufacturing presence. Tobacco Control 2004; 13:151-60.

18 ERC Statistics International plc. The World Cigarettes I and II: The 2001 survey, Suffolk, Great Britain, 2001.

19 European Bank of Reconstruction and Development. Moldova: Investment profile. 2001.

20 Weissman R, White A. Needless Harm, International Monetary fund support for tobacco privatization and for tobacco tax and tariff reduction and the cost to public health. Washington DC: Essential Action, 2002.

21 Food and Agriculture Organization. http://apps.fao.org/page/ collections? subset = agriculture, (Accessed 10 July 2001).

22 United States Department of Agriculture, Foreign Agricultural Service. http://usda.mannlib.cornell.edu/data-sets/specialty/94012/ (Accessed 13 January 2002).

23 Department of International Economic and Social Affairs, Statistical Office. Demographic Yearbook historical supplement. New York: United Nations, 1979.

24 Department of International economic and Social Affairs, Statistical Office. 1987 Demographic Yearbook. New York: United Nations, 1989

25 Department of International economic and Social Affairs, Statistical Office. 1990 Demographic Yearbook. New York: United Nations, 1992.

26 World Health Organisation Regional Office for Europe. European Health for All Database. Copenhagen: WHO Regional Office for Europe, 2002

27 Anon. East European production can be revived. World Tobacco for Russia and Eastern Europe 1996;11:10-16.

28 Prislopeanu I. Eastern Europe: Farewell to monopolies. Tobacco Journal International 2000;5:7-13.

29 Shkolnikov V, Nemtsov A. The anti-alcohol campaign and variations in Russian mortality. In: Bobadilla JL, Costello CA, Mitchell F, eds. Premature death in the New Independent States. Washington DC: National Academy Press, 1997.

30 Anon. World Tobacco File 1997. London: Market Tracking International Limited, 1999.

31 USDA FAS. Azerbaijan, Republic of: Tobacco and Products Annual Report 2000. GAIN Report AJ0002. June 2000. (http://www.fas.usda.gov/ gainfiles/200003/25637244.pdf).

32 Anon. Move towards local sourcing. Tobacco Journal International 1999;4:81

33 Anon. Leaf output growing in Uzbekistan. Tobacco Journal International 1999:5:28.

34 Khan MA. New tobacco factory opened in Kazakhstan. Tobacco Journal International 2000;4:71-2.

35 Rupert J, Frankel G. In ex-Soviet markets, US brands took on role of capitalist liberator. Washington Post, November 19, 1996.
36 Statistical Committee of the Commonwealth of Independent States. External trade of the CIS countries. Moscow: Mezhgosudarstvennyi statisticheskil komitet SNG, 2001.

37 Anon. http://unstats.un.org/unsd/comtrade/ (Accessed 8 November 2004).

38 Joossens L, Raw M. Cigarette smuggling in Europe: who really benefits? Tobacco Control 1998;7:66-71.

39 United States Department of Agriculture, Foreign Agricultural Service. Russian Federation Tobacco and Products Annual 2002, Gain Report \#RS2014, 2002

40 Anon. Russia, Tobacco Traveller. Tobacco Journal International 2000;6:84-85.

41 Anon. World tobacco trends. Henley on Thames: NTC Publications Limited, 1998.

42 ERC Statistics International plc. The World Cigarettes I and II: The 2001 survey, Suffolk, Great Britain, 2001

43 International Trade Publications Ltd. World Tobacco File 1998-2001. London: DMG Business Media, 1998.

44 Forey B, Hamling J, Lee $\mathrm{P}$, et al. International smoking statistics, 2nd ed. Oxford: Oxford University Press, 2002.

45 Gilmore A, McKee M, Telishevska M, et al. Smoking in Ukraine: epidemiology and determinants. Prev Med 2001;33:453-61.

46 Gilmore A, Pomerleau J, McKee M, et al. Prevalence of smoking in 8 countries of the former Soviet Union: results from the living conditions, lifestyles and health study. Am J Public Health 2004;94:2177-87.

47 Volodina S. Ukraine: Mastering the crisis. Tobacco Journal International 2000;4:64-8

48 Shkolnikov V, McKee M, Leon D, et al. Why is the death rate from lung cancer falling in the Russian Federation? Eur J Epidemiol 1999;15:203-6.

49 Dragounski D. Well - this is the Russian market. World Tobacco For Russia And Eastern Europe 1998;II(August):32-46.

50 Gilmore A, Radu-Loghin C, Zatushevski I, et al. Pushing up smoking incidence: plans for a privatised tobacco industry in Moldova. Lancet (in press).

51 Herter U, Brookes N. BAT Industries - Uzbekistan. British American Tobacco. 29 November 1993. Bates No. $202208940-2$.

52 British American Tobacco. Draft 1. Project Umpire skeleton business plan. British American Tobacco. 1994. Bates No. 301734376-, 4406.

53 Anon. http://www.corporateinformation.com/vasector/Advertising.html (Accessed 2 January 2001).

54 Anon http://www.adageglobal.com/cgi-bin/pages.pl?link $=445$ (Accessed 5 April 2002).

55 Zenith Media. Central and Eastern Europe market and mediafact. London: Zenith Optimedia, 2000

56 Marr M, Lewis L. Russia Marketing/distribution study: Yava Factory, Nov. 23Dec. 6 1992. 25/01/1993. Guildford Depository. BAT. Bates No. 500229032-98.

57 British American Tobacco. Russia Business outlook (facts and forecasts). June 1994. Guildford Depository. BAT. Bates No. 203466112-44

58 Bain Link \& Co. BAT Industries Russian distribution strategy final presentation. 21 September 1993. Guildford Depository. BAT. Bates No. 301755203-385.

59 Gilmore A, McKee M, Rose R. Smoking in Belarus: evidence from a household survey. Eur J Epidemiol 2001;17:245-53.

60 McKee M, Bobak M, Rose R, et al. Patterns of smoking in Russia. Tobacco Control 1998;7:22-6.

61 Anon. Russia's Leaf imports rise as cigarette sale fall. World tobacco for Russia and Eastern Europe 1991;1:39-46.

62 Garlick P. Tobacco for the Russian market. Tobacco Journal International 2000;3:34-6.

63 The World Bank. Curbing the epidemic: governments and the economics of tobacco control. Washington DC: The World Bank, 1999.

64 Murray CIL, Lopez AD. Mortality by cause for eight regions of the world: global burden of disease study. Lancet 1997;359:1269-76.

65 Anon. http://apps.fao.org/page/form? collection = Production, Crops. Primary\&Domain = Production\&servlet = 1 \&language $=$ EN\&hostname $=$ apps. fao. org\&version $=$ default (Accessed 10 July 2001)

66 Anon. http://apps.fao.org/page/form? collection = Trade, CropsLivestockProducts\&Domain $=$ Trade\&servlet $=1$ \&language $=$ EN\&hostname = apps.fao.org\&version = default (Accessed 16 September 2002) 